University for Business and Technology in Kosovo

UBT Knowledge Center

Oct 27th, 1:30 PM - 3:00 PM

\title{
Methods for Determining Air Quality in the Microbiological Aspect in the Production of Coal \& Base Fresh Cooling Plates in the “Fluidi” Company, Gjilan-Kosovo
}

Luljeta Ajdini

University for Business and Technology, luljeta_ajdini@hotmail.com

Follow this and additional works at: https://knowledgecenter.ubt-uni.net/conference

Part of the Food Science Commons

\section{Recommended Citation}

Ajdini, Luljeta, "Methods for Determining Air Quality in the Microbiological Aspect in the Production of Coal \& Base Fresh Cooling Plates in the "Fluidi" Company, Gjilan-Kosovo" (2018). UBT International Conference. 177.

https://knowledgecenter.ubt-uni.net/conference/2018/all-events/177

This Event is brought to you for free and open access by the Publication and Journals at UBT Knowledge Center. It has been accepted for inclusion in UBT International Conference by an authorized administrator of UBT Knowledge Center. For more information, please contact knowledge.center@ubt-uni.net. 


\title{
Methods for Determining Air Quality in the Microbiological Aspect in the Production of Coal \& Base Fresh Cooling Plates in the Fluidi Company
}

\author{
Luljeta Ajdini
}

luljeta_ajdini@hotmail.com

\begin{abstract}
This paper provides a biomonitoring activity, based on microorganisms (total number of bacteria, coliform bacteria, E. coli microflora fungus - yeasts and molds. Methods applied during the biomonitoring research work are done in manufacturing facilities and in the internal microbiology laboratory at the "Fluidi" company, in the existing wells, in the spaces where the raw material and the raw material are stored, in the areas where the sugar is stored, in the preparation areas technical water production, sirup preparation chambers, to packing the packaging depending on which type is used and where the final product is assembled, which means mainly in 10 countries based on HACCP principles and needs dependents. The methods used in this evaluation are classical with the placing of Petri's boxes filled with adequate ground for determining the type of microorganisms and the Mas 100 Apparatus. This biomonitoring is of great importance because it affects the assessment of air quality. This assessment identifies the presence of pathogenic microorganisms that may affect the degradation of the produced fluids and the taking of measures to eliminate them in accordance with HACCP requirements. These early, timely data have not been published elsewhere and can be valuable as a contribution to the recognition of pollution as well as to compare their biological quality to the present day.
\end{abstract}

Keywords: Microorganisms, HACCP, Company "Fluidi" Sh.pk

\section{Introduction}

Climatic conditions, the construction of the plant complex "Fluidi" Sh.pk in an environment far away from settlements, the introduction of technology for the technological processes for the production of $\mathrm{C} 02$ and tree-based fluids requires analysis and measurement. Physical chemical and microbiological analyzes are carried out in the company's internal laboratories. These measurements and analyzes that are made for the final product, for the air in the production areas, the water used in the production process, the hygiene of workers, the packaging, sanitary hygiene, etc inside and outside the facility are of great importance for the production process itself and health working personnel and the premises of the complex of manufacturing facilities within the company "Fluidi" Sh.pk It is worth mentioning that the development of processes and the existing situation require an assessment of the quality of air, product, hygiene and sanitary conditions and human health, while not leaving the wider environment as well. This paper provides a part of biomolecular activity based on microflora in the air. In the intern microbiology laboratory in the premises of the company "Fluidi" Sh.pk. the microbiological assessment of the air quality in production areas has been applied for years since 2009 and up to now. This evaluation is of utmost importance that it affects the identification of pathogenic microflores and the taking of measures to eliminate them within the permitted limits. Air biomonitoring is of particular importance in the production process, which ensures quality and safe production and protects the health of workers in the work areas. Today's development and technological processes as well as the 
existing situation require, inter alia, the assessment of air quality as a prerequisite for the efficient use and utilization of fresh air spaces, avoidance of concerns, product preservation and worker health. Failure to observe the HACCP principles of production processing results in air disturbances and other concerns, respectively, increase of microbial pathogenic microbes such as bacteria and so on. The biomonitoring process of the air in the production spaces is done using the classical method and with the MAS-100 apparatus. The following chapters will be used for sampling and location as well as for the results obtained.

Established three decades ago, specifically in 1994 in Presevo and later in 1996 in Gjilan and in the village of Velekinca, with the main goal of offering quality products from natural resources, Fluidi is today considered to be the largest and largest company in Kosovo and in the region for providing natural and carbonated drinks with an international license. In the premises of the company "Fluidi'Sh.pk. are located lines for the production of carbonated drinks in pet packaging with different volumes, cans, little tetra line for the production of fruit-based drinks and that of oil. The production of high-quality liquids, flavor and taste is the primary in "Fluidi" sh.pk company Therefore, we strive to create added value for the conusmators of our products. As a result, we apply the highest quality standards at every step of the production process and implement a continuous quality monitoring system from local and foreign specialists. Serious investment in production lines, biomonitoring and physico-chemical monitoring in laboratories has generally been awarded with two international licenses for applying the best manufacturing practices; ISO 22000: 2005 and HACCP, In addition, HACCP and ISO 22000: 2005 show that Fluid applies a management system through which it ensures that beverage safety, production process, final product, and consumer expectations are at the right level.

\section{Purpose of the study}

Biomonitoring methods are the preferred methods for accurate assessment of living environments and in our case for assessing the quality of air in production facilities. In this way the paper presented aims at: Location of microflorous species found in production areas, nutritional status and air quality. Based on the knowledge of the microflorous species, its definition, methods of identification with methods of planting, incubation and reading of the results, taking measures in cases of air contamination in the production areas in order to preserve the quality production and health of the workers. In this way the application of air quality assessment methods in production facilities is a prerequisite for meeting the requirements of HACCP principles and the requirements of ISO 22000 standard, with which license is provided by the company "FLUIDI" Sh.p.k

\section{Method of sampling}

To achieve the identification of microflores in the air, the classical method and the abovementioned apparatus are applied. Prepare the nutrient grounds specifically for the required microflorum, fill Petrit boxes with a diameter of $90 \mathrm{~cm}$ of glass or plastic with the respective terrain. For each type of microfora there is adequate nutritional ground eg. for identifying the total number I used and used P.C.A. Agar (Plate Counte Agar), for coliform bacteria of fecal origin and E. coli were mainly concentrated on Endo Agar and for fungal microorganisms and yeasts and mold used Rose Bengal agar with chlorophorm. As a selective medium or selective 
feeding ground. After solidification of the terrain if well prepared they are distributed to the enterprises shown in the table above. If microbial microbial microphage identification is used classical methods are Petri dishes placed and left to stay for up to two hours. When using the MAS-100 Microfloor Measuring Device in the production areas then we must know that the device should be calibrated and the battery should be fully charged so make sure the device begins by sampling at the location. Before placing the petri dish on the apparatus with which the medium or nutritive ground will be disinfected with alcohol, the $70 \%$ closure closes the appliance lid and is placed in the high places presented and the coding where for five minutes the appliance is capable of receiving microflores of air of the total number in $500 \mathrm{~m} 3$, while for coliforms and $\mathrm{E}$. colin for 10 minutes it receives $1000 \mathrm{~m} 3$ of air for air and for mold for 5 minutes for 500 $\mathrm{m} 3$ siperfaqe. In the following picture we give the Mas 100 air sampling and sampling mode.
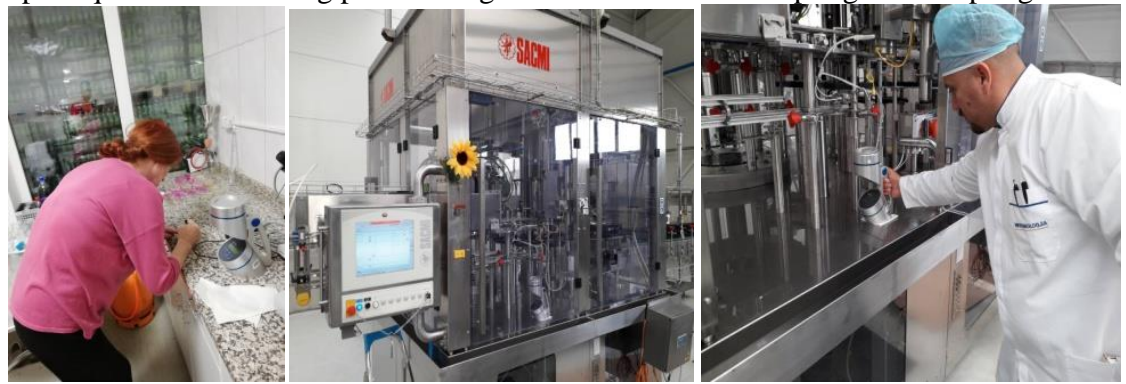

\section{Prepare nutritional grounds}

Nutrients are prepared according to the data in the recipe, they are prepared in white pre-sterilized white glass caps in 2 bar pressure autoclave at 121 degrees Celsius for 25 minutes. Nutritional sites are prepared with bidestilous water after measuring the terrain in the scales and then placed in the microwave for homogenization, since after homogenization you are measured Phe which should be neutrally 7 to 7.5 or even 5.5 to 6.5 depending on the type The feeding ground and microflorous species that are required and then placed on the autoclave in the above procedure, after autoclaving they are thrown into petri dishes with dimensions of $90 \mathrm{~cm}$.

\section{Incubation of the samples.}

This process assists the growth and cultivation of microflores required. Incubation of the total mesophilic microfloor is carried out at the incubator at a temperature of 37 degrees Celsius and a 72-hour standstill, after which the result is littered and reported for faeces and E. coli temp.37 degrees Celsius and 24 hours in situ suspicious in the 48-hour interval after incubation results in reading and evaluation of results while fungus microflora is incubated at 25 degrees Celsius for 120 hours.

\section{The Results}

Are shown after the incubation period, so for the reading totals of 24 and 72 hours, the permissible total permissible total permissible bacteria is less than 10 colonies of bacteria, coliform bacteria of faecal origin and E .coli is 0 while for fungus microflor (leek \& mold) reading starts after 48 hours and 120 hours where allowed norms are 10 yeast colon molds that means 5 teaspoons and 5 molds. 
Tab.1.Weekly report of microbiological analysis of air

\begin{tabular}{|c|c|c|c|c|c|c|c|}
\hline \multirow[t]{2}{*}{$\begin{array}{l}\mathrm{Nu} \\
\mathrm{mbe} \\
\mathrm{r}\end{array}$} & \multirow[t]{2}{*}{$\begin{array}{l}\text { The } \\
\text { sam } \\
\text { pling } \\
\text { venu } \\
\text { e }\end{array}$} & \multirow{2}{*}{$\begin{array}{l}\text { The } \\
\text { samplin } \\
\text { g } \\
\text { volums } \\
\text { \&stand } \\
\text { ards } \\
500 \mathrm{~m} / \\
5 \text { koloni } \\
\text { bakters }\end{array}$} & \multirow{2}{*}{$\begin{array}{l}\text { Total } \\
\text { COUNT } \\
\text { NUMB } \\
\text { ER } \\
\text { bacters } \\
\text { Results } \\
24 \mathrm{~h}, 48 \\
\mathrm{~h} \quad 72 \mathrm{~h}\end{array}$} & \multirow{2}{*}{$\begin{array}{l}\text { The } \\
\text { sampli } \\
\text { ng } \\
\text { volums } \\
\text { \&stand } \\
\text { ards } \\
1000 \\
\text { m3/0 } \\
\text { koloni }\end{array}$} & $\begin{array}{l}\text { COLI } \\
\text { Bact. }\end{array}$ & \multirow{2}{*}{$\begin{array}{l}\text { The } \\
\text { sampli } \\
\text { ng } \\
\text { volums } \\
\text { \&stand } \\
\text { ards }\end{array}$} & $\begin{array}{l}\text { mold } \quad \& \\
\text { yeast }\end{array}$ \\
\hline & & & & & $\begin{array}{l}\text { Resu } \\
\text { lts } \\
24 \mathrm{~h}\end{array}$ & & $\begin{array}{l}\text { Results } \\
24 \mathrm{~h}, 48 \mathrm{~h}, 7 \\
2, \mathrm{~h}, \quad 96 \mathrm{~h}, \\
120 \mathrm{~h}\end{array}$ \\
\hline 1 & & & & & & & \\
\hline 2 & & & & & & & \\
\hline 3 & & & & & & & \\
\hline
\end{tabular}

Once the results are obtained, the results are compared to the allowed norms of the EU standards. In cases of increasing microbiological parameters in the production areas, specifically of the sites after each sanitation process, sanitation needs to be resumed and monitoring again. In our case there are cases of microfloral growth in the air especially during the summer period when there is a large flow of production and big market demands. In cases of contamination of pathogenic microflorous air, co-corrective steps have been taken with hygienic sanitary measures until values are returned to standards.

It should be noted that working environments must be protected from contamination, whether microbial or chemical, because they have consequences for the final product and indirectly affect human health because liquids are consumed by the person at all ages. Contamination of production spaces dependson many ecological factors, as well as light, temperature and humidity. Contamination of production space is also done by the operation of the personnel itself and the introduction of gas heaters in the production spaces.

\section{Conclusions}

Biomonitoring Starting in 2009, far more than ever has played a major role in the quality and safety of the final products produced in the company "Fluidi" Sh.pk. During this biomonitoring I have been able to identify the type of microflor more present in time periods and different weather conditions and annual seasons. The inter-municipal biomonitoring of airborne microbial and fungal microbial biomonitoring has enabled us to identify the pollutant factors and ways of eliminating these factors

In the above explanations, we saw that microbiological biomonitoring is a necessary and necessary requirement for the processes of production of food products that directly affect the life and health of humans

Given the growing demand for pathogenic microfluid airborne applications in line with the requirements of the EU standards in the Kosovo food industry, continuous studies and information are needed. The implementation of contemporary biomonitoring methods would provide further assistance in this regard. There is always a need for regularassessment to 
understand the current situation, to determine the main polluting sources and to decide what will be the main ways of improving the ecological status.

Continued cooperation between institutions within the country and ongoing qualification of experts would always be the only way to solve environmental manufacturing concerns, regardless of the type of food industry and auxiliary products.

\section{References:}

1. Sini K. (2005), Microbiology of Food and Hygiene

2. Hysko M. (2004), Microbiology Practice

3. Plakolli M (2004), Aplied microbiology

4. Good practices of HBC Coca Cola, Zemun Belgrade 2009

5. Manual of Sanitary Inspectorate Tirana 1998 